\title{
Pneumatocele formation in a fatal adult pneumonia patient coinfected with Streptococcus pyogenes emm-type 3 and influenza A: a case report
}

Masahiro Sano ${ }^{1}$, Aya Shimamoto ${ }^{2}$, Nozomi Ueki ${ }^{3}$, Motohiro Sekino ${ }^{4}$, Hiroshi Nakaoka ${ }^{1}$, Masahiro Takaki ${ }^{1}$, Yoshiro Yamashita', Takeshi Tanaka ${ }^{1}$, Konosuke Morimoto ${ }^{1,5}$, Katsunori Yanagihara ${ }^{6}$, Masahiro Nakashima ${ }^{3}$, Kazuto Ashizawa ${ }^{7}$ and Koya Ariyoshi ${ }^{1,5^{*}}$ (D)

\begin{abstract}
Background: A pneumatocele is a transient thin-walled lesion and rare complication in adult pneumonia. A variety of infectious pathogens have been reported in children with pneumatoceles. We report the first case of adult pneumonia with pneumatocele formation that is likely caused by Streptococcus pyogenes and coinfection with influenza A virus.

Case presentation: A 64-year-old Japanese man presented with a one-week history of fever, sore throat, and arthralgia. He was referred to our university hospital for respiratory distress. He required mechanical ventilation in the intensive care unit (ICU). Bacterial culture detected S. pyogenes in the bronchoscopic aspirates, which was not detected in blood. Although a rapid influenza antigen test was negative, an influenza A polymerase chain reaction (PCR) test was positive. Therefore, he was diagnosed with coinfection of influenza A and group A streptococcus (GAS) pneumonia complicated by probable streptococcal toxic shock syndrome. A chest radiograph on admission showed diffuse patchy opacification and consolidation in the bilateral lung fields.

Multiple thin-walled cysts appeared in both middle lung fields on computed tomography (CT). On the following day, the bilateral cysts had turned into a mass-like opacity. The patient died despite intensive care. An autopsy was performed. The pathology investigation revealed multiple hematomas formed by bleeding in pneumatoceles.

Conclusions: There have been no previous reports of a pneumatocele complicated by S. pyogenes in an adult patient coinfected with influenza A. Further molecular investigation revealed that the S. pyogenes isolate had the sequence type of emm3.
\end{abstract}

Keywords: Pneumatocele, Streptococcus pyogenes, emm-type 3, Influenza a, Case report

\footnotetext{
*Correspondence: kari@nagasaki-u.ac.jp

'Department of Infectious Diseases, Nagasaki University Hospital, 1-7-1,

Sakamoto, Nagasaki 852-8501, Japan

${ }^{5}$ Department of Clinical Medicine, Institute of Tropical Medicine (NEKKEN),

Nagasaki University, 1-12-4, Sakamoto, Nagasaki 852-8523, Japan

Full list of author information is available at the end of the article
}

(c) The Author(s). 2020 Open Access This article is licensed under a Creative Commons Attribution 4.0 International License, which permits use, sharing, adaptation, distribution and reproduction in any medium or format, as long as you give appropriate credit to the original author(s) and the source, provide a link to the Creative Commons licence, and indicate if changes were made. The images or other third party material in this article are included in the article's Creative Commons licence, unless indicated otherwise in a credit line to the material. If material is not included in the article's Creative Commons licence and your intended use is not permitted by statutory regulation or exceeds the permitted use, you will need to obtain permission directly from the copyright holder. To view a copy of this licence, visit http://creativecommons.org/licenses/by/4.0/ The Creative Commons Public Domain Dedication waiver (http://creativecommons.org/publicdomain/zero/1.0/) applies to the data made available in this article, unless otherwise stated in a credit line to the data. 


\section{Background}

A pneumatocele is a transient thin-walled lesion containing air in the interstitium of the lung secondary to the partial obstruction of the bronchial lumen and is usually seen in pediatric pneumonia. It is a rare complication in adult pneumonia, and often causes medical emergency such as tension pneumothorax [1-7]. A variety of infectious pathogens have been reported in children with pneumatoceles, such as Staphylococcus aureus [8], coagulase-negative Staphylococcus [8], Streptococcus pneumoniae [8], Haemophilus influenzae [8], Klebsiella pneumoniae [8], Pseudomonas aeruginosa [8], Pneumocystis jirovecii [9], Enterobacter gergoviae [10], Mycobacterium tuberculosis [11], Enterobacter cloacae [12], Escherichia coli [2], and hydrocarbon-induced pneumonia $[8,13]$. The highly pathogenic Streptococcus species S. pyogenes, or group A Streptococcus (GAS), is not an uncommon cause of acute community-acquired pneumonia [14]. It is often characterized by the rapid onset of dyspnea and fever, with the predominant symptom of chest pain and is associated with high rates of pleural effusion and empyema [15]. A 6-year-old boy with a pneumatocele involving S. pyogenes was reported in 1961 [16], but to our knowledge, no adult case of pneumatocele involving $S$. pyogenes has previously been reported.

\section{Case report}

\section{Clinical history}

A 64-year-old Japanese man with a history of diabetes (HbA1c: 7.1\%), hypertension, hyperlipidemia and gastric ulcer presented with a one-week history of fever up to $39.9^{\circ} \mathrm{C}$, sore throat, and arthralgia. He visited a local doctor and was prescribed an antipyretic after the confirmation of a negative rapid antigen test for influenza. Since his general condition continued to worsen for 4 days, he was referred to our university hospital for respiratory distress.

\section{Physical examination/laboratory data/images}

His vital signs were a respiratory rate of $35 / \mathrm{min}$, pulse rate of $130 / \mathrm{min}$, blood pressure of $63 / 40 \mathrm{mmHg}$, body temperature of $37.2{ }^{\circ} \mathrm{C}$, and oxygen saturation of $40 \%$ on room air. His state of consciousness with the Glasgow Coma Scale (GCS) was E3V4M5 (opened eyes in response to voice, confused/disoriented and localized to painful stimuli). Physical examination revealed an inflamed pharynx with swelling of the uvula and apparent coarse crackles in the right chest. Blood tests revealed leukopenia with a nuclear shift to the left, elevated C-reactive protein (CRP) and procalcitonin, severe respiratory failure (arterial blood gas $\mathrm{pH}$ 7.342, $\mathrm{PaCO}_{2} 26.0 \mathrm{mmHg}, \mathrm{PaO}_{2} 37.7 \mathrm{mmHg}, \mathrm{HCO}_{3}{ }^{-}$ $13.7 \mathrm{mmol} / \mathrm{l}$ ), renal failure and metabolic acidosis (Table 1). A chest radiograph on admission demonstrated diffuse ground glass opacities (GGOs) and consolidation in the bilateral lung fields (Fig. 1a). Chest computed tomography
Table 1 Laboratory Data on Admission(normal range)

\begin{tabular}{|c|c|}
\hline \multicolumn{2}{|l|}{ Haematology } \\
\hline $\mathrm{Hb}(11.4-14.8)$ & $14.0 \mathrm{~g} / \mathrm{dl}$ \\
\hline WBC(5000-8000) & $2300 / \mu l$ \\
\hline $\operatorname{Seg}(40-60)$ & $74.0 \%$ \\
\hline Lymp(30.3-40.5) & $21.0 \%$ \\
\hline Mono(3.8-5.5) & $1.0 \%$ \\
\hline Eosino(0-4.5) & $0.0 \%$ \\
\hline Baso(0-1.9) & $2.0 \%$ \\
\hline At-Ly(0-2.0) & $1.0 \%$ \\
\hline $\operatorname{Plt}(18.0-35.0)$ & $16.9 \times 10^{4} / \mathrm{dl}$ \\
\hline \multicolumn{2}{|l|}{ Coagulation } \\
\hline PT-INR(0.84-1.14) & 1.06 \\
\hline APTT(24.0-36.0) & $38.2 \mathrm{sec}$ \\
\hline AT-III(79-121) & $105 \%$ \\
\hline \multicolumn{2}{|c|}{ Arterial blood gas $\left(\mathrm{O}_{2}\right.$ face mask $\left.12 \mathrm{~L} / \mathrm{min}\right)$} \\
\hline $\mathrm{pH}(7.35-7.45)$ & 7.342 \\
\hline $\mathrm{PaCO}_{2}(35.0-45.0)$ & $26.0 \mathrm{mmHg}$ \\
\hline $\mathrm{PaO}_{2}(80.0-100.0)$ & $37.7 \mathrm{mmHg}$ \\
\hline $\mathrm{HCO}_{3}^{-}(20.0-26.0)$ & $13.7 \mathrm{mmol} / \mathrm{l}$ \\
\hline \multicolumn{2}{|l|}{ Biochemistry } \\
\hline $\mathrm{Na}(135-148)$ & $136 \mathrm{mmol} / \mathrm{l}$ \\
\hline$K(3.50-5.30)$ & $3.7 \mathrm{mmol} / \mathrm{l}$ \\
\hline $\mathrm{Cl}(98-106)$ & $105 \mathrm{mmol} / \mathrm{l}$ \\
\hline BUN(8-22) & $98 \mathrm{mg} / \mathrm{dl}$ \\
\hline Cre(0.4-0.7) & $4.41 \mathrm{mg} / \mathrm{dl}$ \\
\hline $\mathrm{TP}(6.7-8.3)$ & $6.8 \mathrm{~g} / \mathrm{dl}$ \\
\hline Alb(4.0-5.0) & $2.9 \mathrm{~g} / \mathrm{dl}$ \\
\hline T.bil(0.3-1.2) & $0.4 \mathrm{mg} / \mathrm{dl}$ \\
\hline AST(13-30) & $126 U / I$ \\
\hline $\operatorname{ALT}(10-42)$ & $41 \mathrm{U} / \mathrm{I}$ \\
\hline ALP(106-322) & $433 \mathrm{U} / \mathrm{I}$ \\
\hline $\mathrm{LDH}(124-222)$ & $1363 \mathrm{U} / \mathrm{l}$ \\
\hline CK(59-248) & $671 \mathrm{U} / \mathrm{I}$ \\
\hline үGTP(13-64) & $35 \mathrm{U} / \mathrm{l}$ \\
\hline Glucose(73-109) & $374 \mathrm{mg} / \mathrm{dl}$ \\
\hline $\mathrm{HbA} 1_{c}(4.9-6.0)$ & $7.1 \%$ \\
\hline \multicolumn{2}{|l|}{ Immunoserology } \\
\hline Rapid influenza antigen & negative \\
\hline Procalcitonin $(<0.06)$ & $3.3 \mathrm{ng} / \mathrm{ml}$ \\
\hline CRP(0-0.14) & $13.8 \mathrm{mg} / \mathrm{dl}$ \\
\hline \multicolumn{2}{|l|}{ Culture } \\
\hline Sputum & Streptococcs pyogenes $1 \times 10^{6}$ \\
\hline Blood & negative \\
\hline
\end{tabular}




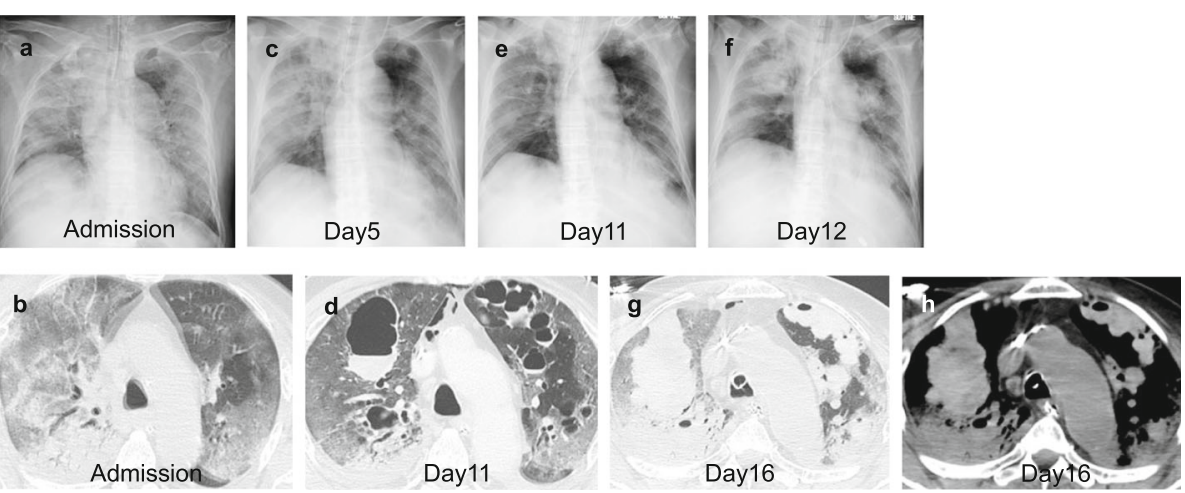

Fig. 1 a Chest radiograph demonstrates diffuse ground glass opacities (GGOs) and consolidation in the bilateral lung fields. b CT shows widespread GGOs and consolidation in the dorsal lungs. c, e Follow-up chest radiographs reveal improvement in GGOs and consolidation in the upper and middle lung fields. Multiple thin-walled cysts appear in both middle lung fields (e). d On CT, GGOs and consolidation are improved, and multiple thin-walled cysts containing a small amount of fluid are seen in both upper lobes. $\mathbf{f}$ Bilateral cysts have turned into a mass-like opacity. $\mathbf{g}, \mathbf{h}$ CT shows enlargement of the cysts and exacerbation of GGOs and consolidation in the background of the lungs. Fluid in the cysts show high attenuation, suggesting bleeding

(CT) showed widespread GGOs and consolidation in the dorsal lungs (Fig. 1b). He required mechanical ventilation (positive end-expiratory pressure: from day 1 to 2, 18 to 15 $\mathrm{cmH}_{2} \mathrm{O}$; from day 3 to 8,12 to $10 \mathrm{cmH}_{2} \mathrm{O}$; and from day 9 , $8 \mathrm{cmH}_{2} \mathrm{O}$ ) in the intensive care unit (ICU).

\section{Diagnosis}

Bronchoscopic aspirates were positive for influenza A by polymerase chain reaction (PCR) at the time of admission and on the 4th day of hospitalization. Bacterial culture detected $S$. pyogenes in the aspirates, which was not detected in blood cultures repeated four times. He was diagnosed with coinfection of influenza A and GAS pneumonia complicated by probable streptococcal toxic shock syndrome (STSS). Because he had hypotension, renal dysfunction and acute respiratory distress syndrome (ARDS) without S. pyogenes bacteremia accompanied by concurrent or sequential infection with influenza A. We actually do not know which infection occurred first: influenza A or GAS pneumonia. Deoxyribonucleic acid (DNA) was extracted from the isolated S. pyogenes and tested by PCR targeting the emm region, which revealed the sequence type of emm3. Furthermore, the virulence genes SpeA and SpeB (but not SpeC) were detected.

\section{Hospital course}

Empirical intravenous antibiotic therapy was immediately initiated as follows: meropenem $1 \mathrm{~g} \mathrm{q12} \mathrm{h}$, linezolid $600 \mathrm{mg} \mathrm{q} 12 \mathrm{~h}$, levofloxacin $500 \mathrm{mg} \mathrm{q} 48 \mathrm{~h}$ and peramivir $600 \mathrm{mg}$ once. Hydrocortisone sodium succinate at 200 $\mathrm{mg} /$ day and pressor agents, including noradrenaline and pitressin, were administered to maintain hemodynamics. He was further supported with continuous hemodiafiltration (CHDF), extracorporeal membrane oxygenation (ECMO) and polymyxin B-immobilized fiber column direct hemoperfusion (PMX-DHP). On day 8, the administered antimicrobial agents were downgraded to ampicillin-sulbactam, clindamycin and levofloxacin following sensitivity results (Table 2). Because the patient's condition was still fragile, we did not narrow the antibiotic spectrum. Follow-up chest radiographs (day 5; Fig. 1c) revealed improvement of GGOs and consolidation in the upper and middle lung fields. On day 11 , multiple thinwalled cysts appeared in both middle lung fields on CT (Fig. 1e). The thin-walled cysts in both upper lobes contained a small amount of fluid (Fig. 1d). On the following day, the bilateral cysts had turned into a mass-like opacity (Fig. 1f) Chest radiograph on day 15 and CT on day 16 showed enlargement of the cysts and exacerbation of GGOs and consolidation in the background of the lungs

Table 2 Streptococcus pyogenes $\left(1 \times 10^{6}\right) \mathrm{MIC}(\mu \mathrm{g} / \mathrm{ml})^{*}$ *Minimum inhibitory concentration

\begin{tabular}{ll}
\hline Daptomysin & $\leqq 0.25$ \\
PenicillinG & $\leqq 0.015$ \\
Ampicillin & $\leqq 0.5$ \\
Ampicillin-sulbactam & $\leqq 0.5$ \\
Cefotaxime & $\leqq 0.5$ \\
Ceftazidime & $\leqq 0.5$ \\
Ceftriaxone & $\leqq 0.5$ \\
Cefepime & $\leqq 0.5$ \\
Meropenem & $\leqq 0.06$ \\
Clarithromycin & $\leqq 0.5$ \\
Clindamycin & $\leqq 0.12$ \\
Vancomycin & 0.5 \\
Levofloxacin & $\leqq 0.5$ \\
Linezolid & $\leqq 1$ \\
\hline
\end{tabular}


(Fig. 1g). Fluid in the cysts showed high attenuation, suggesting bleeding (Fig. 1h). On day 22, multiple organ failure was considered irreversible, and the use of ECMO was terminated. The patient died on day 26. An autopsy was performed. The pathology investigation revealed multiple hematomas formed by bleeding in pneumatoceles on the surface and infiltration of massive inflammatory cells and erythrocytes in the necrotic lung tissue. In addition, vascular destruction was observed. Diffuse alveolar damage (DAD) was widely observed in images of the lungs. The boundary between the hematoma and granulation tissue was unclear, and no covering was found (Fig. 2). No bacteria grew in the cultures of the lung lesions.

\section{Discussion and conclusion}

To our knowledge, this is the first case report of fatal adult pneumonia with pneumatocele formation in which coinfection consisting of S. pyogenes infection and influenza A is thought to have played a role in the pathology.

\section{S. pyogenes pneumonia and its genetic characteristics}

Nelson et al. summarized the case fatality ratio (CFR) for 1509 patients with GAS pneumonia of all ages and revealed a CFR of $27.9 \%$ for elderly individuals aged 65 years and older, which was much higher than 4.4 and $13.8 \%$ for children under 10 years of age and younger adults, respectively [17]. Although there was no evidence of bacteremia, our patient was elderly, and we detected virulence genes, including the streptococcal pyrogenic exotoxin genes SpeA and SpeB, which stimulate T cells as superantigens, resulting in nonspecific $\mathrm{T}$ cell overactivation and massive cytokine release. This process causes tissue damage, organ failure, and septic shock. The isolates in our case were inferred to carry emm3. There seems to be a tendency for serotypes 1 and 3 to be associated with life-threatening infections [17]. Matthias et al. analyzed a large number $(n=719)$ of $S$. pyogenes infections, including meningitis, erysipelas, necrotizing fasciitis, endocarditis, osteomyelitis and pneumonia, and recognized emm 3 as significantly associated with complications of respiratory distress in patients [18]. Despite the negative results of the rapid influenza antigen test, the more sensitive influenza type A PCR was repeatedly positive. We considered this to have had a pathogenic effect. A recently published paper reviewed that underlying influenza A virus infection provokes invasion of GAS, which leads to a fatal condition more often than influenza A infection alone in their mouse model [19].
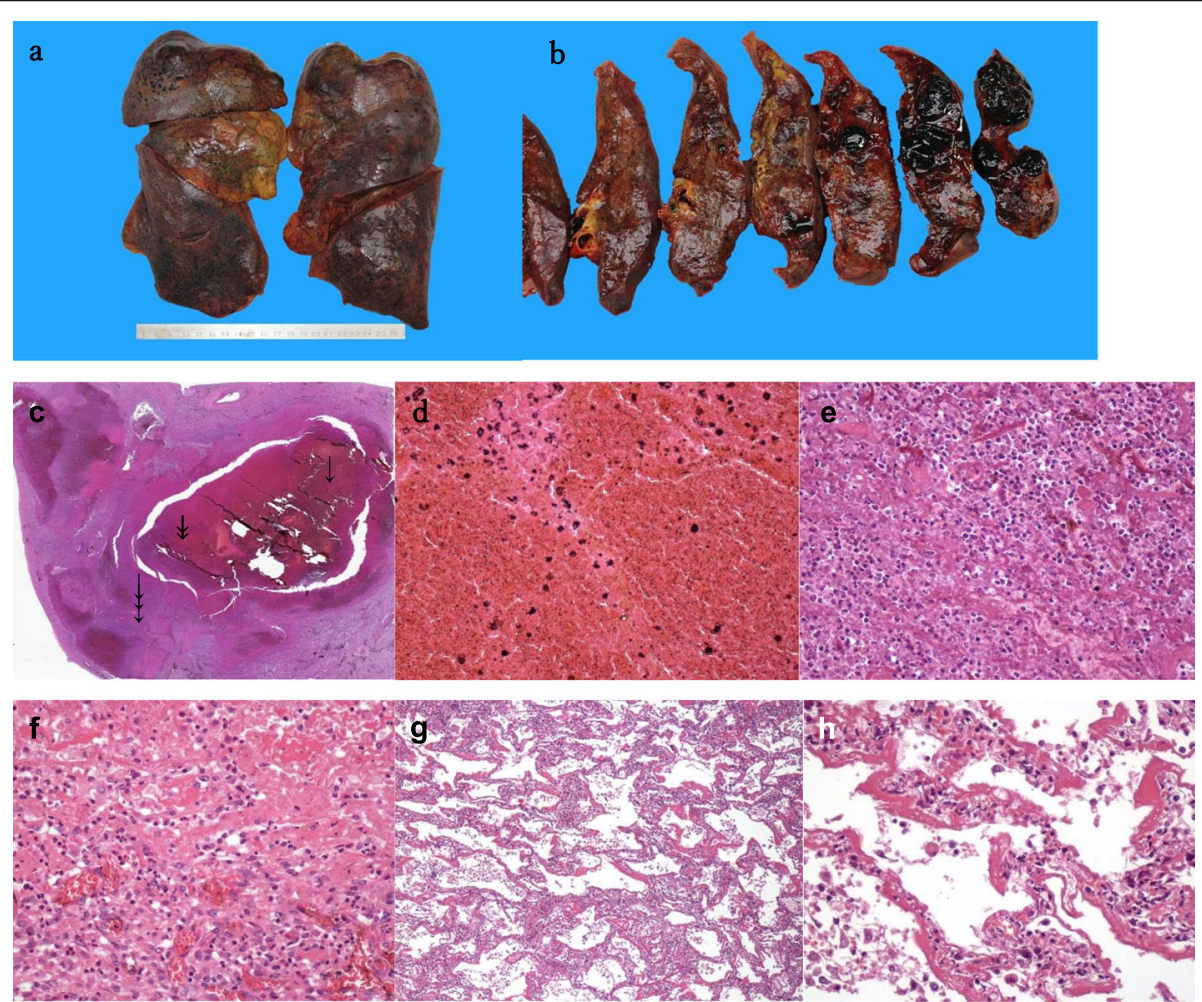

Fig. 2 a Pathological findings. Macroscopically, multiple cysts with necrosis as heavy and hard lung. $\mathbf{b}$ Left lung hemorrhagic cystoid lesion in cut surface. c Hematoma, H.E. stain $\times 1$. d Erythrocytes and fibrin, H.E. stain $\times 200$ in arrow of Fig. 2c. e Necrotic tissue, H.E. stain $\times 100$ in two head arrow of Fig. 2c. $\mathbf{f}$ Capillary vessel and fibroblast in the granulation tissue, H.E. stain $\times 200$ in the three head arrow of Fig. 2C. g, h DAD H.E. $\times 200$ 


\section{Necrotizing pneumonia or pneumatoceles and the timing of its appearance}

According to a previous report, pneumatoceles appear 5-6 days after hospitalization in both children and adults [20]. However, in our case, cystic lesions were not present on day 5 and were noted first on day 11. They were initially assumed to be cavities caused by the toxins produced by $S$. pyogenes destroying the lung tissue, but later CT scan findings indicated thin-walled smoothedged lesions. Pneumatoceles are considered to form as a consequence of the drainage of necrotic lung parenchyma, coupled with check valve and bronchiolar obstruction, which are caused by edematous luminal narrowing with inflammation [21]. Autopsy investigation showed pneumatoceles containing fluid, with necrosis around the pneumatoceles, fibrotic thickening of the alveolar septum and hyaline membranes in the air space. These findings indicate that the pathology was in the proliferative phase of DAD. We believe that this complex pathology arose because this patient survived substantially longer under modern life-support technology, such as CHDF and ECMO. This case report has some caveats. First, we investigated only SpeA, SpeB, and $S p e C$ and no other Spe genes, such as Spe G, $H, I, J, K, L$, and $M$.

Second, we need to consider the correlation between hematoma and CHDF, which affects coagulation dysfunction.

\section{Abbreviations \\ ICU: Intensive care unit; CT: Computed tomography; CRP: C-reactive protein; PCR: Polymerase chain reaction; GAS: Group A streptococcus; \\ DNA: Deoxyribonucleic acid; GCS: Glasgow Coma Scale; EVM: Eye response, Verbal response, Motor response; GGO: Ground glass opacity; CHDF: Continuous hemodiafiltration; ECMO: Extracorporeal membrane oxygenation; PMX- DHP: Polymyxin B-immobilized fiber column direct hemoperfusion; STSS: Streptococcal toxic shock syndrome; ARDS: Acute respiratory distress syndrome; DAD: Diffuse alveolar damage; CFR: Case fatality ratio}

\section{Acknowledgements}

We thank the patient's family for granting permission to publish this report.

\section{Authors' contributions}

MS1, AS, KM, KA1, and KA2 conceived and designed the study. MS1, MS2, $H N, M T, Y Y, T T, K M$, and KA2 cared for the patient. MS1, NU, and MN performed the autopsy. NU and MN conducted the pathological analysis. KY performed the genomic analysis. All authors approved the final version.

\section{Funding}

No funding was received.

\section{Availability of data and materials}

All data generated or analyzed during this study are included in this published article.

\section{Ethics approval and consent to participate}

The overall study design was approved by the Ethical Committee of Nagasaki University Hospital 2020.

\section{Consent for publication}

Written informed consent was obtained from the patient's wife for publication of this case report and accompanying images. A copy of the written consent is available for review by the Editor of this journal.

\section{Competing interests}

The authors declare that they have no competing interests.

\section{Author details}

${ }^{1}$ Department of Infectious Diseases, Nagasaki University Hospital, 1-7-1, Sakamoto, Nagasaki 852-8501, Japan. ²Department of Radiology, Nagasaki University Hospital, 1-7-1, Sakamoto, Nagasaki 852-8501, Japan. ${ }^{3}$ Department of Tumor and Diagnostic Pathology, Atomic Bomb Disease Institute, Nagasaki University Graduate School of Biomedical Science, 1-12-4, Sakamoto, Nagasaki 852-8523, Japan. ${ }^{4}$ Division of Intensive Care, Nagasaki University Hospital, 1-7-1, Sakamoto, Nagasaki 852-8501, Japan. ${ }^{5}$ Department of Clinical Medicine, Institute of Tropical Medicine (NEKKEN), Nagasaki University, 1-12-4, Sakamoto, Nagasaki 852-8523, Japan. ${ }^{6}$ Department of Laboratory Medicine, Nagasaki University Graduate School of Biomedical Sciences, 1-7-1, Sakamoto, Nagasaki 852-8501, Japan. ${ }^{7}$ Department of Clinical Oncology, Nagasaki University Graduate School of Biomedical Sciences, 1-7-1, Sakamoto, Nagasaki 852-8501, Japan.

Received: 1 April 2020 Accepted: 5 November 2020

Published online: 26 November 2020

\section{References}

1. McGarry T, Giosa R, Rohman M, Huang CT. Pneumatocele formation in adult pneumonia. Chest. 1987;92(4):717-20.

2. Colling J, Allaouchiche B, Floccard B, Pilleul F, Monneuse O, Tissot E. Pneumatocele formation in adult Escherichia coli pneumonia revealed by pneumothorax. J Inf Secur. 2005;51(3):e109-11.

3. Kim SH, Chung YT, Lee KD, et al. Infected pneumatocele following anaerobic pneumonia in adult. Korean J Intern Med. 2005;20(4):343-5.

4. Takata S, Yoshioka Y, Naitou H, Kouzuma K, Kinuwaki E. A case of pulmonary tuberculosis with multiple pneumatoceles in adult. Nihon Kokyuki Gakkai Zasshi. 2009;47(2):128-32.

5. Ryou SH, Bae JW, Baek HJ, et al. Pulmonary Pneumatocele in a pneumonia patient infected with extended-Spectrum beta-lactamase producing Proteus mirabilis. Tuberc Respir Dis (Seoul). 2015;78(4):371-4.

6. Sanchez-Toril F, Robles A, Lopez M, Berbegal J, Pasquau F, del Campo F. Pneumatocele as a form of presentation of Pneumocystis carinii pneumonia. Med Clin (Barc). 1991;96(16):621-3.

7. Hunt JP, Buechter KJ, Fakhry SM. Acinetobacter calcoaceticus pneumonia and the formation of pneumatoceles. J Trauma. 2000;48(5):964-70.

8. Amitai I, Mogle P, Godfrey S, Aviad I. Pneumatocele in infants and children. Report of 12 cases. Clin Pediatr (Phila). 1983;22(6):420-2.

9. Holland ET, Saulsbury FT. Chronic Pneumocystis carinii pneumonia associated with extensive pneumatocele formation in a child with human immunodeficiency virus infection. Pediatr Pulmonol. 2003;35(2):144-6.

10. Kesieme EB, Kesieme CN, Akpede GO, et al. Tension Pneumatocele due to Enterobacter gergoviae Pneumonia: A Case Report. Case Rep Med. 2012; 2012:808630.

11. Kao HC, Chiu CH, Lin TY, Wang CR. Pneumonia with pneumatocele formation caused by mycobacterium tuberculosis: report of one case. Zhonghua Min Guo Xiao Er Ke Yi Xue Hui Za Zhi. 1998;39(1):55-7.

12. Glustein JZ, Kaplan M. Enterobacter cloacae causing pneumatocele in a neonate. Acta Paediatr. 1994;83(9):990-1.

13. Makrygianni EA, Palamidou F, Kaditis AG. Respiratory complications following hydrocarbon aspiration in children. Pediatr Pulmonol. 2016;51(6):560-9.

14. Centers for Disease Control and Prevention, ABCs Report: Group A Streptococcus, 2017. https://www.cdc.gov/abcs/reports-findings/survreports/ gas17.html. Accessed 1 July 2020.

15. Birch C, Gowardman J. Streptoccocus pyogenes: a forgotten cause of severe community-acquired pneumonia. Anaesth Intensive Care. 2000;28(1):87-90.

16. Kevy SV, Lowe BA. Streptococcal pneumonia and empyema in childhood. N Engl J Med. 1961;264:738-43.

17. Nelson GE, Pondo T, Toews KA, et al. Epidemiology of invasive group a streptococcal infections in the United States, 2005-2012. Clin Infect Dis. 2016;63(4):478-86

18. Imohl M, Fitzner C, Perniciaro S, van der Linden M. Epidemiology and distribution of 10 superantigens among invasive Streptococcus pyogenes disease in Germany from 2009 to 2014. PLoS One. 2017;12(7):e0180757.

19. Okamoto S, Nagase S. Pathogenic mechanisms of invasive group a Streptococcus infections by influenza virus-group a Streptococcus superinfection. Microbiol Immunol. 2018;62(3):141-9. 
20. Armstrong P. Basic patterns in lung diseases. In: Armstrong P, Wilson AG, Dee P, Hansell DM, editors. Imaging of diseases of the chest. 3rd ed. Spain: Mosby; 2000. p. 115.

21. Ko KS, Lee KS, Kim Y, Kim SJ, Kwon OJ, Kim JS. Reversible cystic disease associated with pulmonary tuberculosis: radiologic findings. Radiology. 1997;204(1):165-9.

\section{Publisher's Note}

Springer Nature remains neutral with regard to jurisdictional claims in published maps and institutional affiliations.

Ready to submit your research? Choose BMC and benefit from:

- fast, convenient online submission

- thorough peer review by experienced researchers in your field

- rapid publication on acceptance

- support for research data, including large and complex data types

- gold Open Access which fosters wider collaboration and increased citations

- maximum visibility for your research: over $100 \mathrm{M}$ website views per year

At $B M C$, research is always in progress.

Learn more biomedcentral.com/submissions 